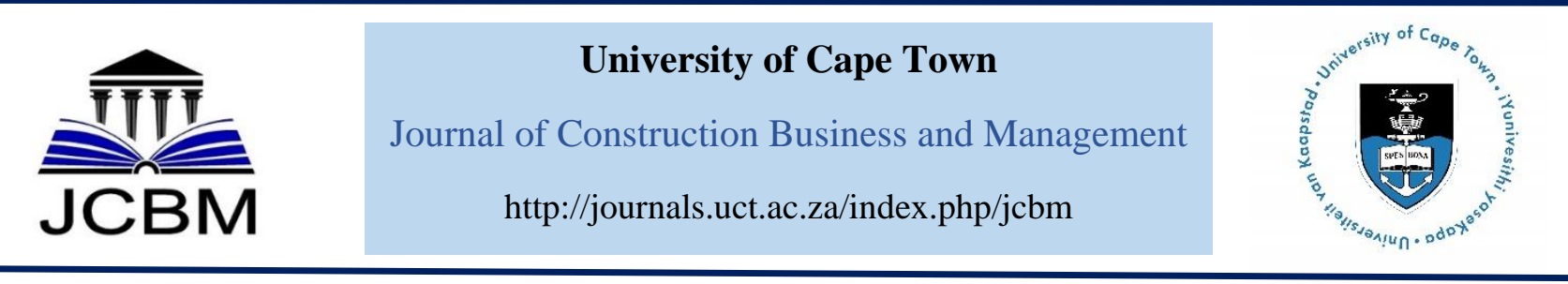

\title{
Pareto Analysis of Critical Risk Factors of Build Operate and Transfer (BOT) Projects in Nigeria
}

\author{
B.S. Waziri ${ }^{1}$ \\ Department of Civil and Water Resources Engineering, University of Maiduguri, Nigeria ${ }^{1}$
}

Received 21May 2017; received in revised form 1July 2017, 18 July 2017, 30 July 2017; accepted 2August 2017

\begin{abstract}
The need to meet the massive infrastructural gaps has led to the adoption of alternative procurement methods. Build Operate and Transfer (BOT) is one of the new ways used for procuring infrastructure. In developing countries, BOT projects are characterised by high-risk profile discouraging private investment. Therefore, it is imperative to identify the critical risk factors inherent in such arrangements with the view to attracting the desired level of private investment. This study employed Pareto Analysis to identify vital risk factors of BOT projects in Nigeria. Structured questionnaires were used to establish critical risk factors based on the perception of key stakeholders (government, concessionaire, lenders, and developers) in Abuja. Kaduna, Port Harcourt and Lagos. Descriptive statistics were used to obtain Standard Deviation of the risk factors indicating their impacts and severity. Based on the results, Pareto Analysis was carried out to separate the "vital few" from the "trivial many". The results indicated nine risk factors as the vital few responsible for $80 \%$ contribution. The risk factors include; changes in government policies, hostile general business environment, project company default, time performance risk, cost performance risk, excessive development cost, instability in government, failure to raise finance for the project and lack of experience in handling the project. Therefore, for effective implementation of BOT projects, it is necessary for stakeholders to focus on the "vital few" risk factors responsible for $80 \%$ of the risk impacts. The results of the study may not be generalised for use by clients and contractors operating in environments with different political and economic climate with Nigeria as the impact and likelihood of occurrence of risks may vary.
\end{abstract}

Keywords: Build-operate-transfer, Nigeria, Pareto analysis, Risk factors.

\section{Introduction}

The challenges of meeting the huge infrastructure needs of most developing countries caused by population explosion and budget constraints have influenced most government agencies to shift from the conventional procurement systems to more innovative types of procurement. One popular option for meeting these demands for infrastructure projects and improvement in service level has been private investment through concession agreements such as the Build Operate and Transfer (BOT). The use of BOT types of contract for the development of infrastructure projects has gained considerable acceptance and is becoming popular in many countries around the world. The BOT arrangement enables clients to have access to funds for the delivery of capital projects through financing partnership between a private and public agency with the parties receiving concessions on design, planning, financing, execution and management of projects (Amusanet al., 2013; Garole and Jarad, 2016). Dankara (2014) observed that BOT had been employed in the last few decades as an alternative procurement route for infrastructure development all over the world. Governments across the world embrace it as a procurement strategy for the provision of infrastructure due to financial constraints and increased demand for such essential services by the citizens. BOT has been successfully deployed in the development of infrastructure projects such as power, engineering, telecommunication and transportation in many countries like USA, UK, Canada, Japan, Indonesia, Malaysia, Singapore and India among others (Amusanet al., 2013).

In Nigeria, several projects were successfully executed through PPP while others failed to be actualized owing to problems of the inadequate legal framework, lack of development finance, inadequate technical among 
other risks (Babatunde et al., 2012; Egboh and Chukwuemeka, 2012). Despite these developments, the federal government had in recent time declared and requests for proposals for many projects through the BOT mechanism indicating the significance and prospects of the financing option for infrastructure development in the country (Mohammed et al., 2012). However, BOT contracts have been identified having a complex risk portfolio leading to the restriction of the award of some concession agreements in Nigeria. This may be attributed to the use of multiple parties with different objectives (Thomas et al., 2006). Furthermore, the successful implementation of BOT projects depends to a considerable extent on the degree to which various risks are identified, managed and allocated (Thomas et al., 2006). Therefore, it is imperative to determine and classify the different risk factors inherent in BOT with the view to providing a platform for effective risk management. This paper attempts to employ Pareto Analysis to identify critical risk factors of BOT projects that are responsible for the greater amount of risk impacts in Nigeria.

\section{Concept of BOT Mechanism}

Several types of PPP arrangements have been utilized for the development of infrastructure in many countries, BOT being the most common and popular arrangement (Garole and Jarad, 2016). Based on the original BOT, different variants have evolved including; Build Own Operate (BOO), Build Lease Transfer (BLT), Build Own Operate and Transfer (BOOT), Build Transfer Operate (BTO), Design Build Finance Operate (DBFO), Rehabilitate Own Operate (ROO) and Rehabilitate Operate Transfer (ROT) among others. These are employed for the development of different types of infrastructure projects in various countries.

Infrastructure projects to be undertaken under the BOT financing mechanism are announced by the government and private sector companies in the different specialisation of construction are invited to submit their proposals for the implementation of the projects. Upon the completion of tender formalities, the successful contractor is selected for the contract. Based on this method the government then grants the advantage of designfinancing-construction- and operation of the project to the chosen private sector for a specific period in the form of a contract (Vosoughi and Vosoughi, 2015). At the end of the contract term, the project manager is responsible for the exploitation of the project and the repayment of the principal amount of received loan and interest on such loans from the proceeds of the project services. An acceptable profit will be paid to the investors of the project from what remains of the earnings. The project company may be responsible for all the stages or may entrust the project to their partners based on an internal contract arrangement. Based on the standard of the contract, at the end of the concession period, the project company transfers all the project assets (financial, physical and legal) to the government and that brings the life of the contract to an end (UNIDO, 1996; Vosoughi and Vosoughi, 2015).
The concession period is one of the key elements of a BOT type of contract which is very significant for its performance. A longer concession period is more beneficial to the private investor which in turn leads to loss of investment to the government (Nasirzadeh et al., 2014). On the other hand, if the concession period is too short, the investor would either reject the contract offer or would be forced to increase the operation fees to recover his investment and make a certain level of profit. Consequently, the risk involved caused by short concession period would be shifted to the end user or users of the facilities (Shen et al., 2002).

\section{Critical Risk Factors of BOT Projects}

The identification and classification of critical risk factors associated with BOT contracts has been a subject of many studies across the world (Tiong, 1990; Woodward, 1992; Chapman and Ward, 2001; Akintoye, et al., 2005; Amusan et al., 2013. Patel, 2013; Sachet al., 2007; Zhang et al., 2008; Wang et al., 2000, Mohammed et al., 2012; Chan et al., 2015; Garole and Jarad, 2016). Tiong (1990) categorised risks in BOT into technical, political, and financial risks. The study revealed that political risk has the highest impact on the implementation of BOT projects. Woodward (1992) considered risks as global (political, legal, commercial) due to wider range and elements (technical, operational, financial and revenue) that are peculiar to a project. The study also demonstrated that both the global and local factors have a significant impact on the achievement of the projects within the desired level of performance. Akerele and Gidado (2003) revealed that from the myriad of risks factors associated with PPP arrangements, political and regulatory risks have the highest regarding severity index. Thomas et al. (2006) noted that private infrastructure under BOT has complex risk portfolio due to factors such as lengthy payback period, lumpiness of huge investment, high developmental efforts and upfront cost, the length of term of the loan, susceptibility to political and economic risk, low market value of security package and a complex construct mechanism involving many participants with diverging interest. Sachet al. (2007) identified currency inconvertibility and transfer restrictions, expropriation, breach of contracts, political violence, legal, regulatory and bureaucratic risks as key risk factors of BOT projects.

Mohammed et al. (2012) classified risk into four categories of political risk, construction risk, operating risk and market and revenue risk. The study indicated that instability in the political system and change in policy affects the effective achievement of BOT projects in Nigeria. Patel (2013) identified a procedure for risk identification and management and its perception from the Indian construction industry players. The study revealed that time constraints and experience of the project manager are crucial for identification of the level of risk for large and complex projects. The study further suggested the integration of time and cost management with the identification process.

Amusan et al. (2013) evaluated risks cost implication from the perspective of concessionaires and professionals. The study revealed that the common risks associated with projects expected are inflation, variation to works, 
changes in judgment policy and the fluctuating nature of the foreign exchange. Renuka al. (2014) observed that early project risk identification and assessment during bidding and incorporation in the bid package would assist in the better estimation of budgets and schedules. The study recommended a simple analytical tool for each project task that would assess risk swiftly for effective analysis.

Chan et al. (2015) identified and evaluated typical risks associated with PPP projects in China. The study revealed that completion risk, inflation and price change risks have a higher impact on Chinese PPP water projects while government corruption, imperfect law, supervision system and change in market demand have a lower impact on the PPP water projects in China. The result of the investigation would to a large extent assist in improving the efficiency of privatisation in public utility service. Garole and Jarad (2016) investigated the risk factors of road projects in India from the perspectives of lenders, developers, contractors and governments. The study identified delay in approval, cost overrun, construction schedule, change in the law, dispatch constraints, land acquisition and compensation, enforceability of the contract, financial closing tariff adjustment and environmental risk as the key risk factors. The study further indicated that the risks are due primarily to the variability of legal systems, market situations and economic climate.

\section{Application of the Pareto Analysis}

According to the Pareto principle, in any group of things that contribute to a common effect, relatively few contributors account for most of the effect. The Pareto principle otherwise known as the 20/80 rule has been originally analysed by the Italian, Vilfredo Pareto who observed that $80 \%$ of property in his country was owned by $20 \%$ of the population (Reh, 2008). Juran and Gryna (1998) further generalised this principle and called it the 'vital few' and 'trivial many' stating that most of the results in any context are raised by a small number of causes.

Harris and McCaffer (2005) also observed that Pareto analysis is a simple technique that helps separate the primary causes of problems from the minor ones providing the management team with a tool for focusing attention on the relevant few. Pareto analysis has been employed as a problem-solving tool in many sectors including the construction industry (Kado et al., 2016). Durnyev and Ismail (2002) employed Pareto analysis to identify the nature of improvement measures of factors causing $80 \%$ of the on-site productivity problems in the New Zealand construction industry. The study established that project management, project finance, workforce, and project characteristics are accountable for the bulk of onsite productivity problems. Kado and Bala (2015) employed Pareto analysis to investigate the prevalence of quality factors of Nigerian design firms. The study identified four key quality section factors which largely influence the performance of the Nigerian design firms. The factors identified are employee training, external design review, design contract review, and performance quality audit. Mahboob et al. (2015) employed Pareto analysis to investigate the critical success factors for total quality management of software engineering. The study concluded that top management commitment was the most common factor followed by customer service and satisfaction. Kado et al. (2016) employed Pareto Analysis to investigate Total Quality Management (TQM) status of the Nigerian design firms. The study revealed that there is a need for the improvement of the status of design firms in Nigeria. The study further indicates deficiencies in the areas of training awareness, education and skills, objective management and feedback and use of TQM tools and techniques.

\section{Methodology}

Primary data for the study was obtained through a field survey while the secondary data was obtained from a review of relevant works of literature from published journals, conference proceedings and fact sheets of local and international organisations. The primary data was obtained using a structured questionnaire randomly distributed to four categories of respondents (government officials, concessionaires, developers and lenders) in Lagos, Port Harcourt, Kaduna and Abuja.

These cities were chosen due to their ample infrastructure projects that have been realised under the BOT financing option. The questionnaire is divided into two sections. The first section captured background information of the respondents, while the second section captures the risk factors associated with BOT contracts established through a literature search. Before the instrument was adopted and administered, it was scrutinised by four (4) experts who have considerable experience and knowledge on the subject matter to satisfy the desired level of validity. The questionnaire was then modified based on the suggestions of the experts before it was administered.

The questionnaire consists of 45 risk factors and provides the participants with the options of rating the factors based on a five (5) point Likert scale, ranging from "very important" to "not important". The population for the study consisted of professionals in the offices of contractors, developers, lenders and government officials. One hundred and twenty (120) questionnaires (30 for each group of respondents) were randomly distributed out of which $98(81.6 \%)$ were returned and 86 corresponding to $71.6 \%$ were found to be fit for analysis. Mean Item Score (MIS) and Mean Deviation (MD) was used to determine the significance and the impact of each risk factor based on the perception of the respondents. The Pareto analysis was then employed by developing Pareto charts to identify the 'vital few' factors that have the greatest impacts from 'trivial many' by adopting the step-by-step procedure outlined by Haughey (2014).

\section{Results and Findings}

\subsection{Profile of Respondents}

The profile of the respondents for the survey is presented in Table 1. 
Table 1: Profile of Respondents

\begin{tabular}{lcc}
\hline Characteristics & Frequency & Percent \\
\hline Category of Respondent & & \\
$\quad$ Government & 24 & 27.91 \\
Concessionaire & 21 & 24.42 \\
Developers & 19 & 22.09 \\
$\quad$ Lenders & 22 & 25.58 \\
Educational Qualification & & \\
$\quad$ High School & 0 & 0.00 \\
Diploma & 18 & 20.93 \\
$\quad$ University Degree/HND & 51 & 59.30 \\
Master/ PhD & 17 & 19.70 \\
Work Experience & & \\
Less than 5 years & 11 & 12.79 \\
5 to 10 years & 16 & 18.60 \\
11 to 15 years & 19 & 22.09 \\
16 to 20 years & 24 & 27.90 \\
Greater than 20 years & 16 & 18.60 \\
Position & & \\
Managing Director & 21 & 24.42 \\
$\quad$ Principal officer & 25 & 29.01 \\
Senior Personnel & 28 & 32.56 \\
Others & 12 & 13.95 \\
Designated Profession & & \\
$\quad$ Engineering & 19 & 22.09 \\
Architecture & 16 & 18.60 \\
Quantity Surveying & 12 & 13.95 \\
Building & 17 & 19.76 \\
Estate Surveying & 12 & 13.95 \\
Others & 10 & 11.63 \\
\hline
\end{tabular}

The demographic profile of the respondents revealed that $27.9 \%$ of the survey participants are from government establishments whereas $24.42 \%, 22.09 \%$ and $25.58 \%$ are from the offices of concessionaires, developers and lenders respectively. The profile further revealed that most of the respondents $(59 \%)$ are first degree holders and $19 \%$ either have a Masters or $\mathrm{PhD}$ degree. The results also show that the majority of the respondents occupy management positions as either principal, deputy directors or directors in their organisations. These results indicate that the information obtained from these categories of respondents can be considered adequate.

\subsection{Risk Factors of BOT}

The results of Mean Item Scores of risk factors are presented in Table 2. The results indicated that changes in government policy which falls under the political risk factor is ranked first which is followed by unfavorable business environment, project company default, time performance risk and cost performance risk. The factors considered to have the least risk are an outbreak of hostilities, strong public opposition and inclement weather.

Table 2: Mean Item Score of Risk Factors

\begin{tabular}{|c|c|c|c|c|}
\hline S/No & Risk Factors & MIS & MD & Rank \\
\hline 1 & Change in government policy & 4.3953 & 0.7658 & 1 \\
\hline 2 & Unfavourable general business environment & 4.2093 & 0.5797 & 2 \\
\hline 3 & Project company default & 4.2093 & 0.5797 & 3 \\
\hline 4 & Time performance risk & 4.1279 & 0.4983 & 4 \\
\hline 5 & Cost performance risk & 4.0814 & 0.4518 & 5 \\
\hline 6 & Excessive development cost & 4.0581 & 0.4286 & 6 \\
\hline 7 & Instability in government & 4.0116 & 0.3821 & 7 \\
\hline 8 & Failure to raise finance for the project & 4.0116 & 0.3821 & 7 \\
\hline 9 & Lack of experience in handling the project & 3.8837 & 0.2542 & 8 \\
\hline 10 & Termination of concession & 3.8721 & 0.2425 & 9 \\
\hline 11 & Changes in project specifications & 3.7558 & 0.1262 & 10 \\
\hline 12 & Quality performance risk & 3.7326 & 0.1030 & 11 \\
\hline 13 & Variation & 3.7326 & 0.1030 & 11 \\
\hline 14 & Force majeure & 3.7326 & 0.1030 & 11 \\
\hline 15 & Inflation risk & 3.7093 & 0.0797 & 12 \\
\hline 16 & Currency risk & 3.7093 & 0.0797 & 12 \\
\hline 17 & Lack of integrity in the tendering process & 3.6977 & 0.0681 & 12 \\
\hline 18 & Change in economic policies & 3.6628 & 0.0332 & 13 \\
\hline 19 & Production target slippage & 3.6047 & 0.0249 & 14 \\
\hline 20 & Default by concessionaire & 3.6047 & 0.0249 & 14 \\
\hline 21 & Nonexistence of legal and regulatory system & 3.6047 & 0.0249 & 14 \\
\hline 22 & Delays in design approval & 3.6047 & 0.0249 & 14 \\
\hline 23 & Foreign exchange & 3.5930 & 0.0365 & 15 \\
\hline 24 & Changes in general legislation affecting the project & 3.5930 & 0.0365 & 14 \\
\hline 25 & Resources risk & 3.5814 & 0.0482 & 16 \\
\hline 26 & Error in operation and maintenance cost estimate & 3.5814 & 0.0482 & 16 \\
\hline 27 & Changes in design during construction & 3.5814 & 0.0482 & 16 \\
\hline
\end{tabular}




\begin{tabular}{lllll}
\hline 28 & Lack of commitment to concession contract & 3.5698 & 0.0598 & 17 \\
29 & Adverse action of the government & 3.5465 & 0.0831 & 18 \\
30 & Lack of expertise & 3.5465 & 0.0831 & 18 \\
31 & Delay in feasibility study & 3.5349 & 0.0947 & 19 \\
32 & Changes in demand for the facility over concession period & 3.4767 & 0.1528 & 20 \\
33 & Complicated negotiations & 3.4535 & 0.1761 & 21 \\
34 & Labor risk & 3.4419 & 0.1877 & 22 \\
35 & Delay in settling claims & 3.4302 & 0.1993 & 23 \\
36 & Flaws in contractual documentation & 3.3953 & 0.2342 & 24 \\
37 & Unfavorable local conditions & 3.3953 & 0.2342 & 25 \\
38 & Expensive and lengthy tendering process & 3.3605 & 0.2691 & 26 \\
39 & Material unavailability & 3.2791 & 0.3505 & 27 \\
40 & Labor shortage & 3.2209 & 0.4086 & 38 \\
41 & Unavailability of quality personnel to operate facility & 3.1628 & 0.4668 & 29 \\
42 & Inappropriate operating methods & 3.1628 & 0.4668 & 30 \\
43 & Outbreak of hostilities (wars, riots and terrorism) & 3.1163 & 0.5133 & 31 \\
44 & Strong public opposition & 2.9651 & 0.6645 & 32 \\
45 & Inclement weather & 2.9535 & 0.6761 & 33 \\
\hline
\end{tabular}

\subsection{Pareto Analysis}

To develop the Pareto chart, the cumulative percentages from the mean scores were calculated and presented in Table 3. The risk factors were assigned the codes (RF) for the 45 factors investigated. The factors were arranged in

Table 3: Cumulative Percentages of Risk Factors descending order as required by the principle of Pareto analysis to compute the cumulative percentage for constructing the cumulative frequency curve (Haughey, 2014).

\begin{tabular}{|c|c|c|c|c|}
\hline Code & Risk Factors & MIS Count & $\%$ of Total & $\begin{array}{c}\text { Cumulative } \\
\text { Percent }\end{array}$ \\
\hline RF1 & Change in government policy & 4.3953 & 2.6973 & 2.6973 \\
\hline RF2 & Unfavorable general business environment & 4.2093 & 2.5831 & 5.2804 \\
\hline RF3 & Project company default & 4.2093 & 2.5831 & 7.8635 \\
\hline RF4 & Time performance risk & 4.1279 & 2.5332 & 10.3967 \\
\hline RF5 & Cost performance risk & 4.0814 & 2.5046 & 12.9013 \\
\hline RF6 & Excessive development cost & 4.0581 & 2.4903 & 15.3917 \\
\hline RF7 & Instability in government & 4.0116 & 2.4618 & 17.8535 \\
\hline RF8 & Failure to raise finance for the project & 4.0116 & 2.4618 & 20.3153 \\
\hline RF9 & Lack of experience in handling the project & 3.8837 & 2.3833 & 22.6986 \\
\hline RF10 & Termination of concession & 3.8721 & 2.3762 & 25.0748 \\
\hline RF11 & Changes in project specifications & 3.7558 & 2.3048 & 27.3796 \\
\hline RF12 & Quality performance risk & 3.7326 & 2.2906 & 29.6702 \\
\hline RF13 & Variation & 3.7326 & 2.2906 & 31.9608 \\
\hline RF14 & Force majeure & 3.7326 & 2.2906 & 34.2514 \\
\hline RF15 & Inflation risk & 3.7093 & 2.2763 & 36.5277 \\
\hline RF16 & Currency risk & 3.7093 & 2.2763 & 38.8040 \\
\hline RF17 & Lack of integrity in the tendering process & 3.6977 & 2.2692 & 41.0732 \\
\hline RF18 & Change in economic policies & 3.6628 & 2.2478 & 43.3209 \\
\hline RF19 & Production target slippage & 3.6047 & 2.2121 & 45.5330 \\
\hline RF20 & Default by concessionaire & 3.6047 & 2.2121 & 47.7451 \\
\hline RF21 & Nonexistence of legal and regulatory system & 3.6047 & 2.2121 & 49.9572 \\
\hline RF22 & Delays in design approval & 3.6047 & 2.2121 & 52.1693 \\
\hline RF23 & Foreign exchange & 3.593 & 2.2049 & 54.3743 \\
\hline RF24 & Changes in general legislation affecting the project & 3.593 & 2.2049 & 56.5792 \\
\hline RF25 & Resources risk & 3.5814 & 2.1978 & 58.7770 \\
\hline RF26 & Error in operation and maintenance cost estimate & 3.5814 & 2.1978 & 60.9748 \\
\hline RF27 & Changes in design during construction & 3.5814 & 2.1978 & 63.1726 \\
\hline RF28 & Lack of commitment to concession contract & 3.5698 & 2.1907 & 65.3633 \\
\hline RF29 & Adverse action of the government & 3.5465 & 2.1764 & 67.5397 \\
\hline RF30 & Lack of expertise & 3.5465 & 2.1764 & 69.7160 \\
\hline RF31 & Delay in feasibility study & 3.5349 & 2.1693 & 71.8853 \\
\hline RF32 & Changes in demand for the facility over concession period & 3.4767 & 2.1336 & 74.0189 \\
\hline RF33 & Complicated negotiations & 3.4535 & 2.1193 & 76.1382 \\
\hline
\end{tabular}




\begin{tabular}{llccc}
\hline RF34 & Labor risk & 3.4419 & 2.1122 & 78.2504 \\
RF35 & Delay in settling claims & 3.4302 & 2.1050 & 80.3554 \\
RF36 & Flaws in contractual documentation & 3.3953 & 2.0836 & 82.4390 \\
RF37 & Unfavorable local conditions & 3.3953 & 2.0836 & 84.5226 \\
RF38 & Expensive and lengthy tendering process & 3.3605 & 2.0622 & 86.5848 \\
RF39 & Material unavailability & 3.2791 & 2.0123 & 88.5971 \\
RF40 & Labor shortage & 3.2209 & 1.9766 & 90.5737 \\
RF41 & Unavailability of quality personnel to operate facility & 3.1628 & 1.9409 & 92.5146 \\
RF42 & Inappropriate operating methods & 3.1628 & 1.9409 & 94.4555 \\
RF43 & Outbreak of hostilities (wars, riots and terrorism) & 3.1163 & 1.9124 & 96.3679 \\
RF44 & Strong public opposition & 2.9651 & 1.8196 & 98.1875 \\
RF45 & Inclement weather & 2.9535 & 1.8125 & 100.00 \\
\hline
\end{tabular}

The Pareto chart presented in Figure 1 was constructed using the cumulative percentage counts of the risk factors based on the procedure outlined by Haughey (2014). The broken line on the chart separates the vital few (top 20\%) from the trivial many $(80 \%)$.

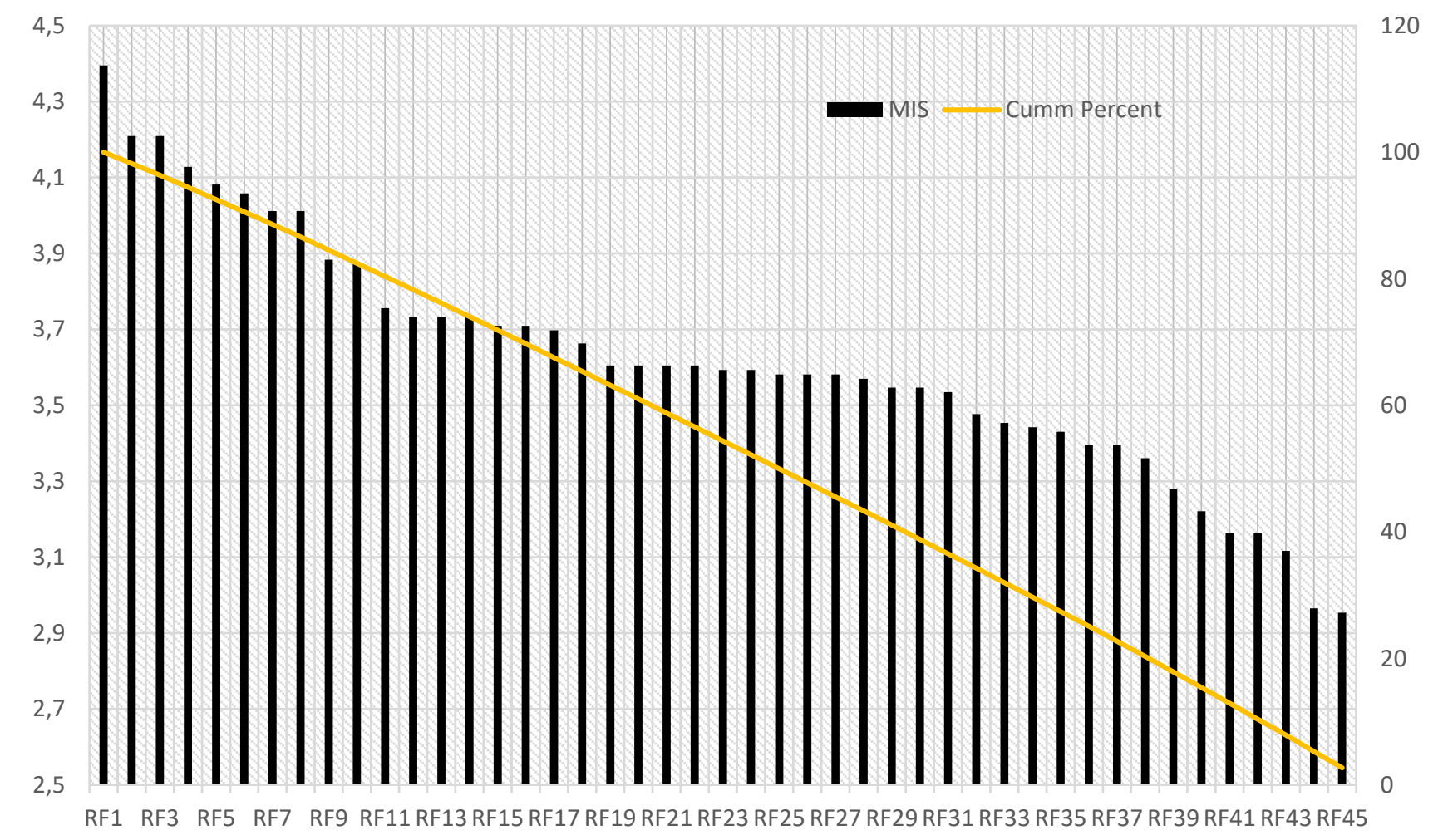

Figure 1 Pareto Chart of Risk Factors

From the Pareto chart, the nine highest risk factors are established to be the vital few (20\%). These factors are a change in government policy, unfavorable general business environment, project company default, time performance risk, cost performance risk, excessive development cost, instability in government, failure to raise finance for the project and lack of experience in handling the project.

\section{Discussion of Results}

Change in government policy is one of the vital risk factors which impact the effective realisation of BOT projects in Nigeria. This is in consensus with the studies of Akerele and Gidado (2003), Amusan et al. (2013) and Vosoughi and Vosoughi(2015) in which change in policies concerning infrastructure projects and instability in government were identified as a critical risk factor for adequate conception and implementation of BOT projects. Government's opinion regarding policies relating to the benefit of a project is critical for pulling government's effort toward such project. Risks associated with the political environment are common in most developing countries (Schaufelberger, 2005). Therefore, it is essential to mitigate against the political risk to have effective implementation of BOT projects.

A hostile general business environment tends to discourage private sector investment thereby defeating the quest for the public-private partnership mechanism necessary for infrastructure project development. The general business climate relates to the economic environment, such as currency devaluation, foreign exchange fluctuation, fluctuation in interest rates, and inflation. These risks were particularly significant for a 
BOT project in Nigeria. These risks affect the cost of debt service and the real value of the projected revenue. The impact of this type of risk on BOT projects in other parts of the world is evident from the study of Schaufelberger (2005). Project company default is a vital risk factor of BOT projects that is requiring the utmost attention during project implementation. A myriad of factors are responsible for the nonperformance of project firms. It is, therefore, necessary to consider companies with a track record of performance for capital projects. This is in agreement with the study of Garole and Jarad (2016) which showed that the effectiveness and efficiency of the private company are crucial toward actualizing BOT projects in developing countries.

Time performance risk essentially affects the implementation of infrastructure project within the time frame and projected cost. Time performance risk may be caused by technical difficulties, poor management or by the combination of both (Schaufelberger, 2005). Akerele and Gidado (2003), Jefferies and Chan (2015) and Chan et al. (2015) indicated that many PPP projects had failed in China due in large part to construction completion (scheduled) risk. Moreover, delays in completion of concession projects will certainly lead to shortened operational life which reduces the investors' income. However, if a project could not start operation as scheduled, the private company would not have sufficient cash flow to pay for the debt and charges on borrowed funds resulting in an extension of operation time which increases operating cost and reduces profit (Chan et al., 2015). Since BOT investors rely on income from the completed project to recover their investment, any delay in completion will certainly delay the generation of revenue.

Cost performance risk is also a vital factor that should be focused upon while engaging in BOT projects. Cost performance of infrastructure projects is a desired criterion for measuring success. The cost performance of BOT projects is however affected by a plethora of other factors leading to cost overrun which will impact the profitability of the project by increasing construction and financing cost. The impact of cost overrun on the implementation of BOT projects was also established by Schaufelberger (2005). Therefore, key stakeholders should focus on these factors to carefully and effectively mitigate the risk factor.

Some private investors are not too enthusiastic about bidding for a BOT project due to excessive development cost which they may never recover. Therefore, it is imperative for decision-makers to pay more attention to this risk factor because its effect on project viability is more critical and risk management techniques are required to mitigate and minimize its effects. The instability in government results in cancellation or revision of contracts. In developing countries, it is imperative to mitigate against political risks, since the most important political changes often occur. Before the implementation of BOT projects, it is necessary for the promoter to conduct a thorough political risk profile to minimise the risk. Every investment is subjected to political risk due to an unstable government and its component, and low foreign reserves.
The performance of the concessionaire is crucial in seeking for the fund to implement a BOT project. Usually, equity risk is related to the performance of the company which is measured by the share price of the enterprise. The capability of the company in raising capital for the BOT project is reflected in the share price. The equity investors and other long-term investors will only agree to provide the amount of funding for BOT project when the promoter has proven the financial capability of the project over its entire lifespan. Therefore, the competence in carrying out detailed and comprehensive feasibility study, economic and risk assessment study would ensure the promoter to be in better position in obtaining domestic equity finance for funding the BOT project. Lack of experience in similar projects by any of the key stakeholders is another critical risk factor which requires attention for the successful achievement of infrastructure project under the BOT mechanism. Therefore, it is desirable for stakeholders to determine the level of experience of all key players on the type of project in question during the early phase in order to effectively handle such project.

\section{Conclusion}

This study employs Pareto analysis in identifying critical risk factors that have a great impact on the implementation of BOT project in Nigeria. The attractiveness of the BOT concept stems from the difficulties many developing countries are facing in both finding sufficient public funding for infrastructure and in attracting private infrastructure investors. The study has found that nine risk factors with the highest criticality Index as the vital few (20\%) that are responsible for $80 \%$ of the risk impact of BOT projects in Nigeria. The risk factors identified are a change in government policy, unfavourable general business environment, project company default, time performance risk, cost performance risk, excessive development cost, instability in government, failure to raise finance for the project and lack of experience in handling the project. The study also found that some risk factors including labour shortage, unavailability of personnel, inappropriate operating method, outbreaks and hostilities, public opposition and inclement weather, among others, constituting the "trivial many" which is considered to have a low impact on the implementation of BOT projects. Although this study is based on the perception of key stakeholders, it highlighted the significance and the impact of the investigated risk factors for the effective implementation of BOT projects in developing countries. The study further exposed the critical risk factors that play a crucial role in the implementation of infrastructure projects within schedule and planned budget and consequently provided the possibility to carefully assess the impact and likelihood of occurrence of such risk to effectively realise BOT projects in Nigeria. It is recommended that, for successful project implementation, key stakeholders of such projects should ensure that appropriate measures are geared toward mitigating these risk factors by allocating risk to parties that best able to control the risks for improved service delivery.

The generalisation of the results of the study is limited by the population for the study which comprised of 
respondents from construction organisations in Nigeria. Therefore, the results of the study may not be entirely useful to clients and contractors operating in environments with different political and economic

\section{References}

Akerele, D and Gidado, K. 2003. The Risks and Constraints in the implementation of PFI/PPP in Nigeria: In Greenwood D.J. (ed). 19th Annual ARCOM Conference3-5th September, University of Brighton 1:379-391

Akintoye, A; Bing, L; Edwards, P.J and Hardcastle, C. 2005. Critical Success Factors for PPP/PFI Projects in the UK Construction Industry. Construction Management and Economics, 23,459-71.

Al-Azemi, K and Bhamra, A. 2014. Risk Management for Build Operate and Transfer Projects in Kuwait. Journal of Civil Engineering and Management, 20(3):415-433

Babatunde, S.O., Opawole, A. and Akinsiku, O. E. 2012. Critical Success Factors in Public-Private Partnership (PPP) on Infrastructure Delivery in Nigeria. Journal of Facilities Management, 10(3): 212-225.

Chan, A.P.C., Lam, P.T., Wen, Y., Ameyaw, E.E., Wang, S. and Ke. Y. 2015. Cross Sectional Analysis of Critical Risk Factors of Public Private Partnership Water Projects in China. Journal of Infrastructure Systems, 21(1): 0401-0431

Egboh, E. A. and Chukwuemeka, E. (2012). Public Private Partnership in Nigeria: The challenge of Human Relation Management. Kuwait Chapter of Arabian Journal of Business and Management Review, 1(5).

Garole, A.P. and Jarad, G.P. 2016. Risk in Build Operate and Operate BOT infrastructure Projects. A case study of Shirwal-Lonad-Phaltan-Baramati Road Project. International Journal of Recent and Innovation Trends in Computing and Communication, 4(1):192-197

Haughey, D. 2014. Pareto Analysis, Step-by-step. Retrieved from www.projectsmart.co.uk/Pareto analysis

Juran, J.M. and Gryna, F.M. 1988. Quality Control Handbook (4th edition): McGraw Hill.

Kado, D. and BalaKabir 2015. Pareto Analysis on the Quality Section/Factors Prevalence of Nigerian Design Firms. In Raiden, A.B. and Aboagye-Nimo, E. (Eds) Proceedings 31st Annual ARCOM Conference, 7-9 September 2015; Lincoln UK, Association of Researchers in Construction Management, 895-904.

Kado, D., Bala, K. and Dandajeh, M.A. 2016. Pareto Analysis on the Total Quality Management (TQM) Status of the Nigerian Design Firms. ATBU Journal of Environmental Technology. 9(1): 42-57

Amusan, L.M., Joshua, O. and Oloke, C.O. 2013. Performance of Build Operate and Transfer Projects Risks Cost Implications from Professionals and Concessionaires Perspective. European International Journal of Science and Technology, 2 (3):239-250

Mahboob, T., Tariq, B., Anwar, S., Jinnah, F and Khanum, M. 2015.Pareto Analysis of Critical Success Factors for Total Quality Management Targeting the Service Industry. International Journal of Computer Applications, 121 (14): 20-24 climate with Nigeria as the impact and likelihood of occurrence of risks may vary.

Mohammed, I.Y. Bala, K and Kunya, S.U. 2012. Risk in Build Operate Transfer Projects in Nigeria. Journal of Environmental Sciences and Resources Management, 4(2012): 29-39

Nasirzadeh, F., Khanzadi, M and Alipour, M. 2014. Determination of Concession Period in Build-OperateTransfer Projects Using Fuzzy Logic. Iranian Journal of Management Studies, 7(2):437-456.

Patel, k. 2013. A study of Risk Assessment and its Management in India. American Journal of Civil Engineering, 1(2):64-67

Reh, J.F. 2008. Pareto's Principle - The 80-20 Rule, How the 80/20 rule can help you to be more effective, about Management, http://management.about.com/cs/generalmanagement/par eto, last accessed 18th February 2017

Renuka, S.M. Umarani, C.S. and Kamel, S. 2014. A Review on Critical Risk Factors in the Lifecycle of Construction Projects, Journal of Civil Engineering Research 4(2A):31-36

Sach, T. and Tiong, L.K.R. and Wang, S.Q. 2007. Analysis of Political Risk and Opportunities in PPP in China and Selected Asian Countries Survey Results, Chinese Management Studies 1(12): 26-148

Schaufelberger, J.E. 2005. Risk Management on BuildOperate-Transfer Projects. Construction Research Congress, 2005, 7574: 1-10

Shen, L.Y. Platten, A. and Devy, X.P. 2006. Role of Public Private Partnership to Manage Risks in Public Sector in Hong Kong. International Journal of Project Management 24(7): 587-594

Thomas, A.V. Khalidini, N.K. and Ganesh, L.S. 2006. Modelling and Assessment of Critical Risk Factors in Build Operate and Transfer BOT Road Projects, Construction Management and Economics. 24: 407-427

Tiong, L.K.R. 1995. Risks and Guarantees in Build Operate and Transfer tender. Journal of Management in Engineering, 121(12):183-188

UNIDO 1990. Guidelines for Infrastructure Development through the BOT Projects UNIDO, 1996

Vosoughi, V. and Vosoughi, P. 2015. Survey, the Necessity of Use and Risk Identification in BOT Contracts. Cumhuriyet University, Faculty of Science Journal (CSJ) Vol36 (6): 290-796

Woodward D. 1992. Use of Sensitivity Analysis in Build Operate and Transfer BOT project Evaluation, International Journal of Project Management 13(4):239246

Wang, S.Q., Tiong, L.K.R., Ting, S.K. and Ashley, D. 2000. Evaluation and Management of Political Risk in Chinas Build Operate and Transfer. Journal of Construction Engineering and Management, 126(3): 242250

Zhang L.J., Arthur, P.J.M. and Tao. F. 2008. Public Private Partnerships in China's Urban Water Sector. Environmental Management, 41(6):863-872 